\title{
Effects of Coronatine on Some Physiological Properties of Plant Cells
}

\author{
Ryutaro SAKAI* \\ 酒井隆太郎*：植物細胞の生理的性質に対するコロナチンの影響
}

\begin{abstract}
Cell wall free protoplasts were prepared from coleoptiles of oats and Italian ryegrass. When the protoplasts were exposed to $1 \mathrm{mM}$ coronatine and $0.6 \mathrm{M}$ mannitol, protoplasmic streaming stopped and cytoplasm aggregated toward one side of the protoplasts within 30 min. At this initial stage, the plasma membrane seemed to have spherical shape and smooth surface, and then the protoplast contracted with time. Plasmolytic ability remained in the epidermal root hair cells of host plant after treatment with coronatine at $2.5 \mathrm{mM}$ or $1 \mathrm{mM}$ for 24 and $48 \mathrm{hr}$. On the other hand, coronatine-induced hypertrophy of potato tuber tissue were markedly inhibited by $\mathrm{N}, \mathrm{N}$-dicyclohexyl-carbodiimide. The results suggest a close association between coronatine and membrane-bound ATPase. In addition, coronatine already changed the permeability $24-48 \mathrm{hr}$ before the development of hypertrophy on potato tuber tissues. These results suggest that the disruption of the cytoplasm induced by coronatine may be due to secondary effects brought about indirectly by physiological changes in the plasma membrane.
\end{abstract}

(Received September 22, 1980)

\section{Introduction}

Most pathogenic strains of Pseudomonas syringae pv. coronafaciens (Reddy and Godkin) Young, Dye and Wilkie, the incitant of chocolate spot disease on Italian ryegrass (Lolium multiflorum Lam), produce coronatine, a new physiologically active substance causing hypertrophy on potato tuber discs ${ }^{4,7)}$. Coronatine induces necrosis with chlorotic halo symptoms in host plants. The symptoms produced by coronatine on Italian ryegrass are similar to those naturally elicited by the pathogen ${ }^{3)}$. On the other hand, coronatine induces marked hypertrophy in potato tuber discs. More recently, it has been shown that mutants of Ps. syringae pv. coronafaciens lacking the ability of producing coronatine are not pathogenic on Italian ryegrass, the host plant of the bacteria ${ }^{4}$. Considering the fact that coronatine is a phytotoxic substance, the physiological activity of coronatine may be one of the essential requirements for the pathogenicity of the bacterium. The work reported here deals with the physiological change in plant cells treated with coronatine.

\section{Materials and Methods}

Coronatine was isolated from the culture filtrate of Ps. syringae pv. coronafaciens and

\footnotetext{
* Obihiro University of Agriculture and Veterinary Medicine, Obihiro, Hokkaido 080, Japan 帯広 畜産大学環境植物学研究室
} 
purified according to previously described procedures ${ }^{6}$. Cellulase ONOZUKA R-10 was purchased from Kinki Yakult MFG. Co., Ltd.

Preparation of protoplasts. Protoplasts from coleoptiles of oats and Italian ryegrass were prepared with cellulase by the method of Ruesink and Thimann ${ }^{5}$. Seeds of Avena sativa var. Victory and Lolium multiflorum var. Mammoth A were soaked for $2 \mathrm{hr}$ and planted on moist filter paper and exposed to red light for $24 \mathrm{hr}$. They were then kept in the dark at $25 \mathrm{C}$ with intermittent dim red light until the coleoptiles were $20 \mathrm{~mm}$ long. To improve the penetration of cellulase, the epidermal cells were removed from each coleoptile in 4-6 clean strips, peeling from the base to the tip with fine forceps under dim red light. A $5 \mathrm{~mm}$ subapical section was then cut from the remaining tissue and the primary leaf removed. Two such sections were cut into $1 \mathrm{~mm}^{2}$ pieces and placed in an enzyme-mannitol mixture consisting of $2 \%$ cellulase solution with $6 \mathrm{M}$ mannitol

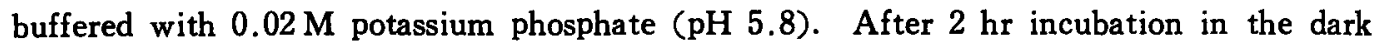
at $22 \mathrm{C}, 10$ volumes of $0.5 \mathrm{M}$ mannitol buffered at $\mathrm{pH} 5.8$ were added. Protoplasts settled to the bottom of the tube in $10 \mathrm{~min}$ and the supernatant was removed with a pipette. Mannitol solution was again added and the procedure was repeated to remove cellulase. The spherical protoplasts showed active protoplasmic streaming.

Test for plasmolytic ability. Roots of 4 days old plants of Italian ryegrass (var. Mammoth A) grown on water-soaked filter paper in Petri dishes were placed in coronatine solution at $1 \mathrm{mM}$ and $2.5 \mathrm{mM}$, respectively. After treatment, roots were quickly rinsed in water, then placed in $0.7 \mathrm{M}$ mannitol solutions, and observed under a microscope. Cells with damaged membranes are not plasmolyzed when placed in hypertonic solutions.

DCCD treatment. Potato tuber discs, $3 \mathrm{~mm}$ thick and $11 \mathrm{~mm}$ in diameter, were obtained as reported earlier ${ }^{3,6,7)}$. The discs were immersed in $\mathbf{N}, \mathrm{N}^{\prime}$-dicyclohexyl-carbodiimide (DCCD) solution for $30 \mathrm{~min}$ at $25 \mathrm{C}$. These discs were rinsed twice with water. After weighing the discs they were placed on moistened filter paper in the Petri dishes. Ten microliters of coronatine solution at concentration of $0.5 \mathrm{mM}$ were added on each discs and incubated at $23 \mathrm{C}$ for 5 days. Discs were weighed at the end of the incubation.

Ion leakage in plant tissues. The effects of coronatine on ion leakage from potato tuber discs and Italian ryegrass leaves were measured by the change in the electrical conductivity of suspending solutions. The conductivity of the ambient solution was measured at given intervals with a model CM-IDB TOA Electronics Ltd conductivity brige, using a dip type electrode cell. Results were expressed as specific conductance in $\mu \mathrm{mhos} /$ unit fresh weight of tissue.

\section{Results}

\section{Effect of coronatine on free protoplasts}

The protoplasts were transferred to concavity microscope slides and treated with a solution containing $1 \mathrm{mM}$ coronatine and $0.6 \mathrm{M}$ mannitol. The basic reaction mixture was $10 \mu \mathrm{l}$ protoplast suspension plus $10 \mu \mathrm{l}$ treatment solution. The slides were incubated at $23 \mathrm{C}$ in a moist chamber. A microscope was used to take zero time counts of intact protoplasts, followed by counts at varying intervals. Survival percentages were based on zero time counts. As shown in Fig. 1, the protoplasts were affected within $30 \mathrm{~min}$ after exposed to a coronatine solution at $1 \mathrm{mM}$. Initially, protoplasmic streaming stopped and 


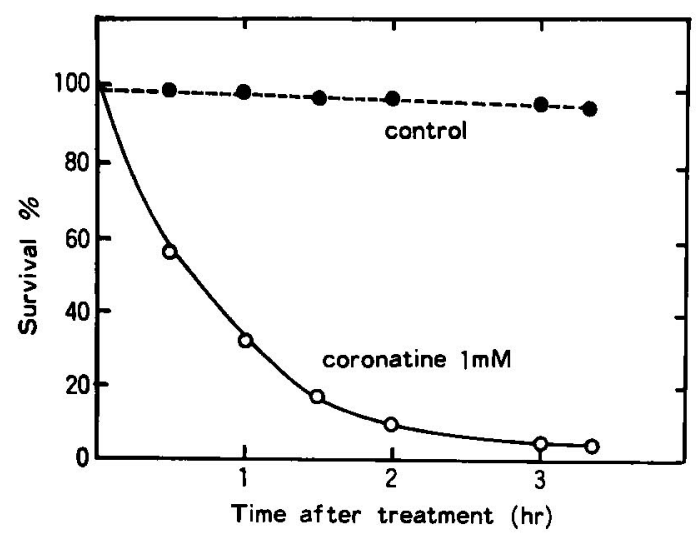

Fig. 1. Effect of coronatine $(1 \mathrm{mM})$ on survival of oat protoplasts. Protoplasts were treated with coronatine in $0.5 \mathrm{M}$ mannitol. Calculated as $\%$ of intact protoplasts at zero time.
Table 1. Effect of coronatine on plasmolysis of epidermal root cells of Italian ryegrass in hypertonic solutions

\begin{tabular}{|c|c|c|}
\hline \multirow{2}{*}{ Treatment } & \multicolumn{2}{|c|}{$\begin{array}{c}\text { Plasmolytic } \\
\text { ability }\end{array}$} \\
\hline & $24 \mathrm{hr}^{2)}$ & $48 \mathrm{hr}^{2)}$ \\
\hline $\mathrm{H}_{2} \mathrm{O}$ (control) & + & + \\
\hline Coronatine $1 \mathrm{mM}$ & + & $+b)$ \\
\hline $2.5 \mathrm{mM}$ & $+b)$ & - \\
\hline
\end{tabular}

a) Length of time which the cells were treated with coronatine

b) Plasmolytic ability were remained normal, but the cytoplasmic contents appeared to be granulated in structure.

+ : Normal plasmolysis

-: Not plasmolysis
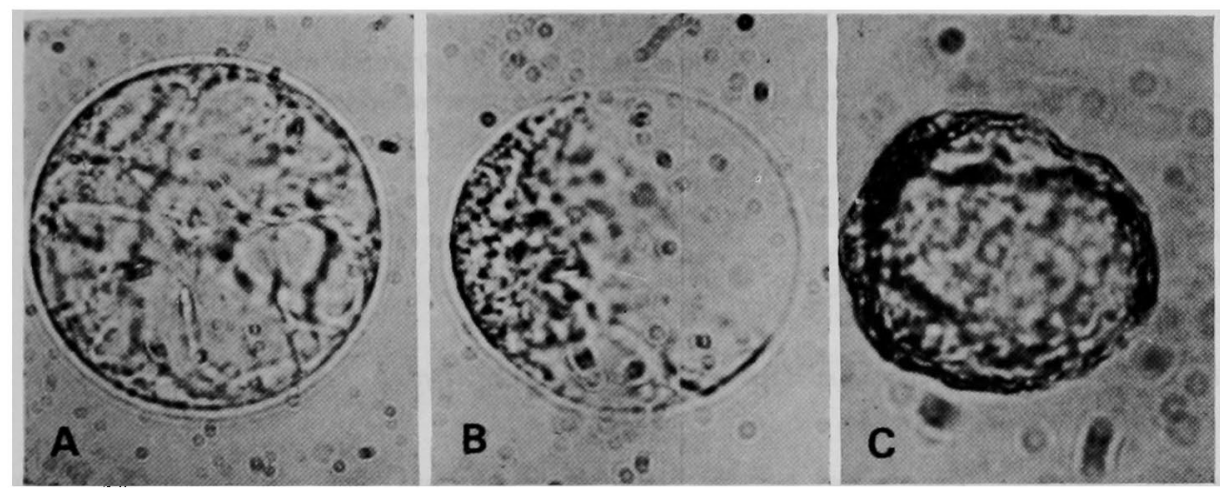

Fig. 2. Effect of coronatine on protoplast isolated from epidermal cells of oat coleoptile. Protoplasts were treated with a solution containing $1 \mathrm{mM}$ coronatine and $0.6 \mathrm{M}$ mannitol. $\mathrm{A}$ : Solvent control ( $0.6 \mathrm{M}$ mannitol). B : 30 min after treatment cytoplasm aggregated toward one side of the protoplasts. C: $60 \mathrm{~min}$ after treatment the protoplast contracted with time.

then the cytoplasm turned light brown in color. The cytoplasm aggregated toward one side of the protoplast. Thus, there appeared to be slight destruction in the structure of the cytoplasm. At this initial stage, the plasma membrane seemed to have spherical shape and smooth surface and then the protoplast contracted with time (Fig. 2).

\section{Effect of coronatine on the plasmolytic ability of cells}

Damage of the plasma membrane results in the loss of plasmolytic ability of cells. The effects of coronatine on cell membranes were examined. As shown in Table 1, plasmolytic ability remained in the epidermal root hair cells of Italian ryegrass at 24 and $48 \mathrm{hr}$ after exposure to coronatine at $2.5 \mathrm{mM}$ and $1 \mathrm{mM}$, respectively. However, it appeared 
to cause a slight granulation in the structure of the cytoplasm. These results indicated that coronatine seemed to injure the cytoplasm before the plasmolytic ability of the plasma membrane was lost.

\section{Effect of $N, N$-dicyclohexylcarbodiimide ( $D C C D$ ) on coronatine-induced hypertrophy}

The effect of DCCD at various concentrations on the hypertrophy of the potato tuber discs in the absence or presence of $0.5 \mathrm{mM}$ coronatine was examined. As shown in Fig. 3, the coronatine-induced hypertrophy of potato tuber discs was clearly affected by $0.5 \mathrm{mM}$ DCCD and was markedly inhibited by $1 \mathrm{mM}$ DCCD.

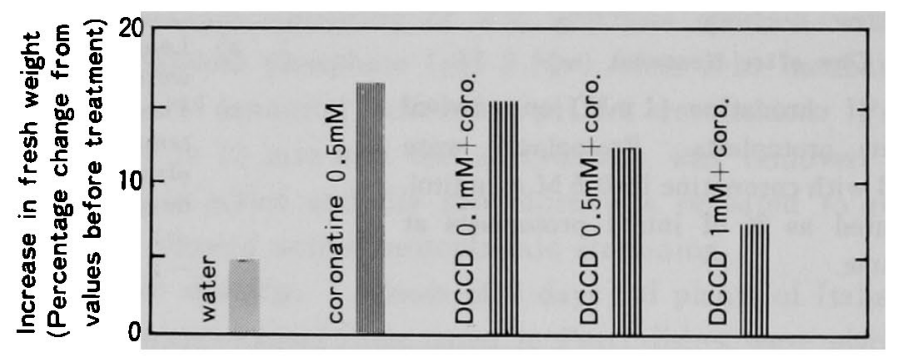

Fig. 3. Inhibition of coronatine-induced hypertrophy of potato tuber discs by $\mathbf{N}, \mathrm{N}^{\prime}$-dicyclohexylcarbodiimide (DCCD). Potato tuber discs, $3 \mathrm{~mm}$ thick and $11 \mathrm{~mm}$ in diameter, were pretreated with DCCD for $30 \mathrm{~min}$ and the discs were incubated with coronatine for 5 days. Each bar represents the mean 10 sections. coro., coronatin, 0.5 $\mathrm{mM}$; DCCD, $0.1 \mathrm{mM}, 0.5 \mathrm{mM}, 1 \mathrm{mM}$.

\section{Effect of coronatine on the loss of electrolytes from potato tuber and Italian ryegrass leaves}

Potato tuber Five gram potato tuber discs ( $2 \mathrm{~mm}$ thick and $8 \mathrm{~mm}$ in diameter) were added with $10 \mu$ l coronatine at concentration range from $0.25 \mathrm{mM}$ to $1 \mathrm{mM}$ and incubated for $40 \mathrm{hr}$ on filter paper moistened with water in Petri dishes. After incubation the discs were placed in $50 \mathrm{ml}$ of distilled water to measure the loss of electrolytes as described previously. After mesurement, the discs were replaced to the same Petri dishes and incubated more 2 days under the same condition. As shown in Fig. $4 \mathrm{~A}$, coronatine treated potato tuber discs released electrolytes at much faster rate than did the control. Conductance of the ambient solution of treated discs at concentration of $1 \mathrm{mM}$ coronatine for $20 \mathrm{hr}$ was two times greater than that of control. After two days of the measurement, hypertrophic growth occurred on the potato tuber discs.

Italian ryegrass leaves Leaf cuttings of two months old plants were allowed to take up coronatine $(0.1 \mathrm{mM}$ or $0.5 \mathrm{mM})$ or water as control for $20 \mathrm{hr}$. Following treatment, the leaf blades were cut into $0.5 \mathrm{~cm}$ pieces. The tissues $(0.5 \mathrm{~g})$ were enclosed in washed gauze bags and incubated in $50 \mathrm{ml}$ of distilled water at $23 \mathrm{C}$ to measure the loss of electrolytes as described previously. As show in Fig. $4 \mathrm{~B}$, coronatine-treated leaf sections released electrolytes at a much faster rate than did the control during one hr 
leaching period. After $21 \mathrm{hr}$ coronatine treatment at concentrations of $0.1 \mathrm{mM}$ or $0.5 \mathrm{mM}$, the specific conductance of the ambient solution of the tissues was two or three times more than that of control.
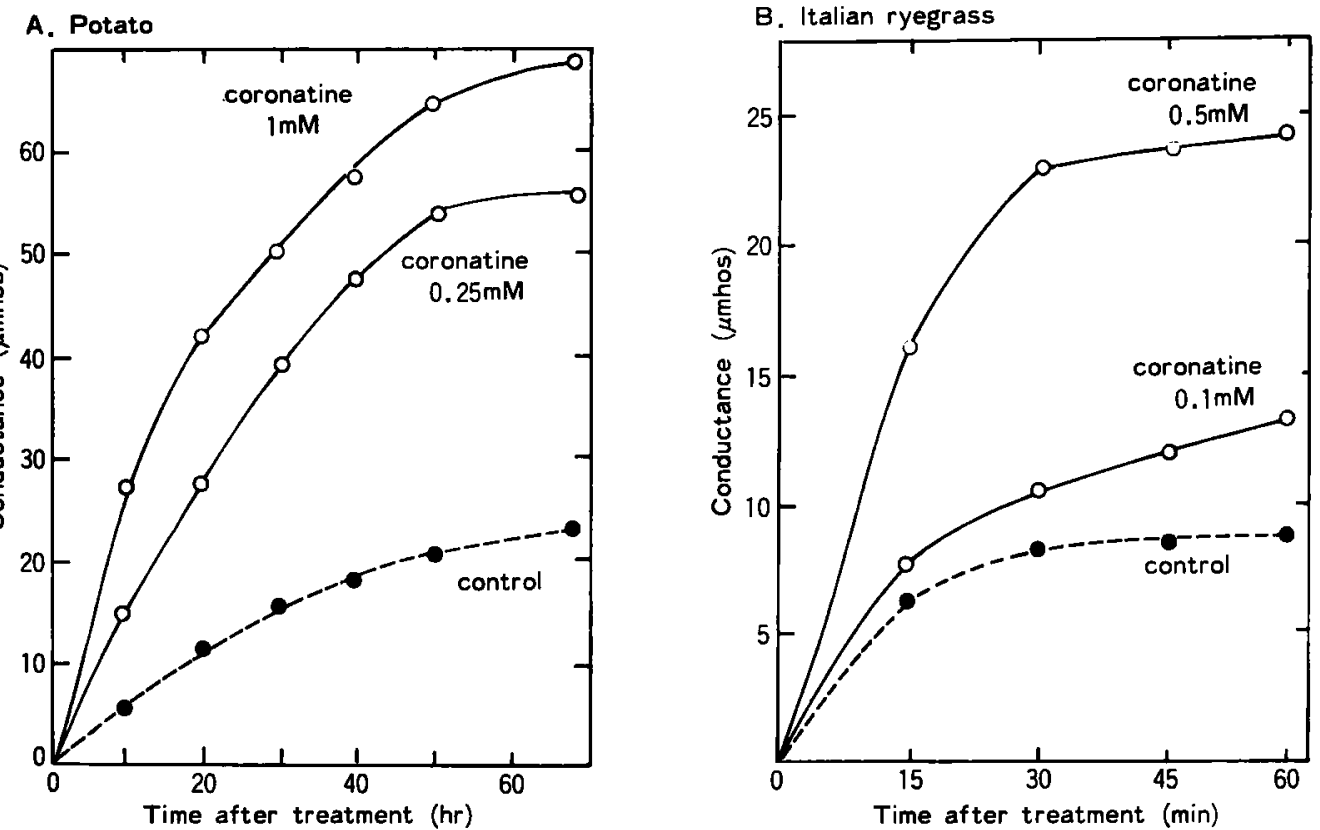

Fig. 4. Effect of coronatine on the loss of electrolytes from discs of potato tuber and leaf tissues of Italian ryegrass. A : Potato discs were treated with $10 \mu$ l coronatine at $0.25 \mathrm{mM}$ or $1 \mathrm{mM}$ for $40 \mathrm{hr}$. B : Leaf cuttings of Italian ryegrass were allowed to take up coronatine at $0.1 \mathrm{mM}$ or $0.5 \mathrm{mM}$ for $20 \mathrm{hr}$. Electrolyte loss from toxintreated and control tissues was determined by conductance measurement of the ambient solution at the indicated intervals.

\section{Discussion}

A discussion of the results reported above can be focussed on two main points: (i) site of a primary lesion for coronatine as a phytotoxin in plant cells and (ii) physiological changes in plasma membrane caused by coronatine. The experiments with isolated protoplasts are of interest for the initial lesion site of coronatine in plant cells. Samadder and Scheffer indicated that HV-toxin, produced by Helminthosporium victoriae, quickly disrupt the plasma membrane of suscetible cells, and the initial effect is thought to be on this structure ${ }^{8}$. In the present experiments, when cell wall-free protoplasts in host cells were incubated with coronatine at $1 \mathrm{mM}$, it appeared to be abnormal in the structure of the cytoplasm, and then the cytoplasm aggregated toward one side of the protoplast within $30 \mathrm{~min}$ after treatment. Similar results have been obtained independently from the experiments of plasmolytic ability of cells. In general, cells with damaged plasma membrane are not plasmolyzed when placed in hypertonic solutions. As shown in Table 1 , when the epidermal root cells of Italian ryegrass were incubated with coronatine at 1 $\mathrm{mM}$ or $2.5 \mathrm{mM}$, plasmolytic ability remained at $48 \mathrm{hr}$ and $24 \mathrm{hr}$, respectively. The cytoplasmic contents appeared to be slightly granulated. 
Recently, the role of membrane-bound ATPases have been considered in relation to the mechanisms of plant hormonal action. Marre et al. have reported that in pea internode segments, DCCD inhibited both auxin-induced cell enlargement and proton extrusion, suggesting the close association of auxin action and plasma membrane-bound ATPase ${ }^{2}$. If it is assumed that coronatine induced cell enlargement is closely associated with its stimulation of membrane-bound ATPase, then antagonism between coronatine and DCCD would be expected in cell enlargement. Data obtained in this experiments, DCCD, an inhibitor of membrane-bound ATPase, inhibited coronatine-induced hypertrophy on potato tuber discs. This result suggests a close association between coronatine and membranebound ATPase. Change in permeability might be the initial event in pathogenesis. Several pathogens are known to produce toxins which cause a rapid increase in the loss of electrolytes from host tissues. Coronatine was tested for similar effects on leaf cutting of Italian ryegrass and tuber discs of potato. Data obtained in the present experiments indicated that significant permeability changes occur when potato tuber discs and leaf cuttings of Italian ryegrass are treated with coronatine. Two days after the measurement of electrolytes, hypertrophic growth occurred on the potato discs. The result indicates that coronatine changes the permeability $24-48 \mathrm{hr}$ before the development of hypertrophy on potato tuber tissues. These data suggest the possibility that coronatine might initially affect the physiological changes in plasma membrane. Thus, these studies of initial lesion sites for coronatine in host plant suggest that the disruption of the cytoplasm induced by coronatine may be secondary effects brought about indirectly by physiological change in the plasma membrane. Further studies are needed to solve the problem as to whether the physiological change in the plasma membrane caused by coronatine is responsible for the disruption of the cytoplasm.

\section{Literature cited}

1. Kasamo, K. and Yamaki, T. (1974). Plant Physiol. 15 : 965-970.

2. Marré, E. P. Lado., Rasi-Coldogno, F. and Colombo, R. (1973). Plant Sci. Letters 1: $185-192$.

3. Nishiyama, K., Sakai, R., Ezuka, A., Ichihara, A., Shiraishi, K., Ogasawara, M., Sato, H. and Sakamura, S. (1976). Ann. Phytopath. Soc. Japan. 42 : 613-614.

4. Nishiyama, K. and Ezuka, A. (1978). Ibid. $44: 179-183$.

5. Ruesink, A. and Thimann, K. V. (1965). Botany $54: 56-64$.

6. Sakai, R., Nishiyama, K., Ichihara, A., Shiraishi, K. and Sakamura, S. (1979). Ann. Phytopath. Soc. Japan. 45 : 645-653.

7. Sakai, R., Nishiyama, K., Ichihara, A., Shiraishi, K. and Sakamura, S. (1979). In Recognition and Specificity in Plant Host-Parasite Interactions (Daly, J. M. and Uritani, I. eds.). Tokyo and University Park Press, Baltimore. pp. 165-179.

8. Samaddar, K. R. and Scheffer, R. P. (1968). Plant Physiol. 43: 21-28. 
和 文 摘 要

\section{植物細胞の生理的性質に対するコロナチンの影響}

\section{酒 井 隆太郎}

宿主の子葉鞘より調製した遊離ブロトブラストにュロナチンを接触させると傷害が起こる。その過程は， 最初原形質流動が停止し，次いで細胞質が黄褐変化し，やがて細胞質はプロトブラストの一方に片寄って凝 集する。明らかに紐胞質構造の異常が認められる。しかしこの時点で原形質膜の構造は，光顕的には健全ブ ロトブラスト同様の状態を保つものが観察される。また，イタリフンライグラス根毛をコロナチンに接触さ せると，表皮細胞の細胞質構造に異常が認められるが，その細胞に原形質分離能が保持される場合が観察さ れる。一方, ジャかイモ塊茎柔組織細胞のュロナチンによる肥大作用が, DCCD (原形質膜結合 ATPase 活 性の特異的阻害剂)によって阻害され，またイタリフンライグラス葉片およびジャガイモ塊茎の組織をコロ ナチンで処理すると，組織細胞より電解質が漏出する。これらの実験結果は，コロナチンは作用初期の段階 で, 植物の原形質膜の生理的性質に各種の影辢を与えることが予想される。以上の結果，イタリアンライグ ラスかさ枯病菌の生産する病原毒素ュロナチンの病徵発現機構を解明するためには, コロナチンの原形質膜 に対する生理的作用が，細胞質の破壊にどのように関連するかを明らかにする必要があろら。 